\title{
EPISTEMOLOGI ISLAM (SEBUAH KONSEP ISLAM TENTANG PENGEMBANGAN ILMU DAN GERAKAN INTELEKTUAL)
}

\author{
JAENULLAH
}

\begin{abstract}
As a result of Western epistemology which privileges the role of humans in solving everything and at the same time opposes the spiritual dimension which later becomes the main source of the epistemological crisis which has implications for the crisis of knowledge, there is an attempt to find solutions by considering other epistemologies. Among Muslim thinkers offer that solution with Islamic epistemology. The idea or idea of Islamic epistemology aims to provide space for Muslims in particular, in order to get out of the shackles of understanding science based on Western epistemology need to be straightened out to avoid misunderstandings and even worse actions while in the plains of idealism, the idea of forming Islamic epistemology is efforts to save Muslims from the intellectual trap and the epistemological building of Islam in that formulated based on the Qur'an and Al-Sunnah as God's revelation.
\end{abstract}

Kata Kunci: Epistemologi Islam, Ilmu, dan Gerakan Intelektual.

\section{A. PENDAHUluan}

Ilmu pengetahuan dan teknologi yang hingga saat ini menjadi kunci yang paling mendasar dari kemajuan yang diraih umat manusia, tentunya tidak datang begitu saja tanpa ada sebuah dinamika atau diskursus ilmiah. Proses untuk mendapatkan ilmu pengetahuan itulah lazim dikenal dengan istilah epistemologis. ${ }^{1}$

Dalam kajian epistemologi (theory of knowledge), bahwa pengetahuan dimulai dengan rasa ingin tahu. ${ }^{2}$ Dari perasaan inilah yang mengantarkan manusia untuk mengubah ketidaktahuan menjadi "tahu".Namun untuk mengetahui sesuatu, manusia tidak sekedar mencari tanpa alat dalam memperoleh pengetahuan, melainkan melalui bahkan selalu bergantung pada alat-alat dan cara-cara untuk dapat mengetahui sesuatu tersebut.Sebab pengetahuan memiliki bermacam-macam jenis dan 
sifatnya, yakni ada pengetahuan yang sifatnya langsung dan tidak langsung, dan ada yang bersifat obyektif umum dan ada pula yang bersifat subyektif khusus.Oleh karena itulah, ilmu pengetahuan sangat bergantung pada sumbernya. ${ }^{3}$

Tetapi, sumber pengetahuan dalam epistemologi sendiri selaludipertanyakan, yakni apakah bersandar pada suatu otoritas, atau persepsi indera,atau akal-budi, dan atau bahkan bersandar kepada intuisi semata. ${ }^{4}$ Dari sinilahkeberadaan manusia terlihat sangat jelas bahwa manusia sebagai makhluk pencaripengetahuan (penafsir realitas) merupakan tindakan yang mulia dihadapan Tuhan,dan dari sini pulalah letak keunggulan manusia sebagai makhluk ciptaan Tuhandibandingkan dengan makhluk-makluk lain-Nya, sehingga dalam dunia pemikiran, epistemologi menempati posisi penting, sebab ia menentukan corak pemikiran dan pernyataan kebenaran yang dihasilkannya. Bangunan dasar epistemologi berbeda dari satu peradaban dengan yang lain. ${ }^{5}$

Perbedaan titik tekan dalam epistemologi memang besar sekali pengaruhnya dalam konstruksi bangunan pemikiran manusia secara utuh. Pandangan dunia manusia akan terpengaruh bahkan dibentuk oleh konsepsinya tentang epistemologi. Oleh karena itu perlu pengembangan empirisme dalam satu keutuhan dimensi yang bermuatan spiritualitas dan moralitas. ${ }^{6}$ Sehingga diharapkan epistemologi Islami akan lahir dan memberi jawab atas kegelisahan umat dewasa ini.

Epistemologi Islam ini diharapkan menjadi suatu pendekatan keilmuan yang memiliki kekuatan besar dalam mengembangkan ilmu pengetahuan baru dan teknologi yang berkepedulian terhadap lingkungan, baik lingkungan geografis, lingkungan sosial maupun lingkungan budaya. Dengan kata lain, epistemologi Islam menjadi media mewujudkan ilmu pengetahuan dan teknologi yang beradab. Ilmu pengetahuan dalam Islam memiliki karakteristikkhas yang berbeda secara 
fundamental dengan ilmu-ilmu yangdikembangkan di Barat, baik landasan, sumber, sarana, danmetodologinya. Dalam Islam, ilmu pengetahuan memilikilandasan yang kokoh melalui al-Qur'an dan Sunnah; bersumberdari alam fisik dan alam metafisik; diperoleh melalui indra, akal,dan hati/intuitif. Cakupan ilmunya sangat luas, tidak hanyamenyangkut persoalan-persoalan duniawi, namun juga terkaitdengan permasalahan ukhrawi.Untuk itu, makalah ini akan mencoba untuk mengurai permasalahan yang berkaitan dengan pengertian ilmu pengetahuan dalam Islam, epistemologi ilmu pengetahuan dalam Islam, dan konsep Islam dalam pengembangan ilmu dan gerakan intelektual

\section{B. KONSEP Islam Tentang PENGEMbangan Ilmu dAN GERAKan INTELEKTUAL}

Sebagaimana diketahui, bahwa salah satu gagasan yang paling canggih, amat komprehensif, dan mendalam yang ditemukan di dalam alQur'an ialah konsep ilm. Pentingnya islamisasi ini terungkap dalam kenyataan adanya istilah ilmu dan turunannya di dalam Al-Qur'an sekitar 800 kali. Dalam sejarah peradaban muslim, konsep ilmu secara mendalam meresap ke dalam seluruh lapisan masyarakat dan mengungkapkan dirinya dalam semua upaya intelektual. ${ }^{7}$

Dalam perspektif sejarah, perkembangan ilmu pengetahuan dan gerakan intelektual dalam Islam mengalami pasang surut. Suatu ketika mencapai puncak kejayaan, dan di saat yang lain mengalami kemunduran. Ilmu dalam berbagai bidangnya mengalami kemajuan yang pesat di dunia Islam pada zaman klasik, yaitu sejak zaman Nabi Muhammad SAW, sampai dengan akhir masa daulah Abbasiyah di Baghdad. ${ }^{8}$ 
Sejarah politik dunia Islam biasanya dipetakan ke dalam tiga periode, yaitu; periode klasik (650-1250 M), periode pertengahan (12501800 M), dan periode modern (1800-sekarang). ${ }^{9}$ Dari ketigaperiode tersebut, yang dikenal sebagai masa keemasan Islam adalah periode klasik, yang antara lain ditandai dengan etos keilmuan yang sangat tinggi, yang ditunjukkan dengan pesatnya perkembangan ilmu pengetahuan di berbagai bidang kehidupan.

Akselerasi perkembangan ilmu pengetahuan di dunia Islam sangat tampak setelah masuknya gelombang Hellenisme melalui gerakan penerjemahan ilmu-ilmu pengetahuan Yunani ke dalam bahasa Arab, yang dipelopori khalifah Harun al-Rasyid (786-809 M) dan mencapai puncaknya pada masa khalifah al-Makmun (813-833 M).Beliau mengirim utusan ke kerajaan Romawi di Eropa untuk membeli sejumlah manuscripts untuk kemudian diterjemahkan ke dalam bahasa Arab. ${ }^{10}$ Sejak itu para ulama mulai berkenalan dan menelaah secara mendalam pemikiranpemikiran ilmuwan Yunani seperti Pythagoras (530-495 SM), Plato (425347 SM), Aristoteles (388-322 SM), Aristarchos (310-230 SM), Euclides (330260 SM), Klaudios Ptolemaios (87-168 M), dan lain-lain.

Tidak lama kemudian muncullah di kalangan umat Islam para filosof dan ilmuwan yang ahli dalam berbagai disiplin ilmu pengetahuan. Sekedar menyebut contoh misalnya, dalam bidang kedokteran muncul; alRazi (866-909 M), Ibn Sina (wafat 926 M), Ibn Zuhr (1091-1162 M), Ibn Rusyd (wafat 1198 M), dan al-Zahrawi (wafat 1013 M). Dalam bidang filsafat muncul; al-Kindi (801-862 M), al-Farabi (870- $950 \mathrm{M})$, al-Ghazali (1058-1111 M), dan Ibn Rusyd (wafat 1198 M). Dalam bidang ilmu pasti dan ilmu pengetahuan alam muncul; al- Khawarizmi (780-850 M), alFarghani (abad ke-9), an-Nairazi (wafat 922 M), Abu Kamil (abad ke-10), Ibrahim Sinan (wafat 946 M), al- Biruni (973-1051 M), al-Khujandi (lahir 1000 M), al-Khayyani (1045- 1123 M), dan Nashirudin al-Thusi (1200-1274 
M). Perkembangan dalam bidang hukum Islam ditandai dengan lahirnya empat imam madzhab; Abu Hanifah (wafat 767 M), Anas ibn Malik (wafat 795 M), Muhammad ibn Idris al-Syafii (wafat 819 M), dan Ahmad ibn Hambal (wafat 855 M).Dalam bidang Hadits, muncul sejumlah ulama Hadits terkemuka seperti; Bukhari (wafat $870 \mathrm{M}$ ), Muslim (wafat $875 \mathrm{M}$ ), Ibn Majah (wafat $886 \mathrm{M}$ ), Abu Dawud (wafat $886 \mathrm{M}$ ), al-Tirmidzi (wafat 892 M), dan al-Nasa'i (wafat 916 M).Dalam bidang teologi muncul ulama semacam; Abu al-Hudzail al- Allaf, Ibrahim al-Nazzam, Abu al-Hasan alAsy'ari, dan Abu Manshur al-Maturidi. ${ }^{11}$ Penerjemahan ilmu pengetahuan dan filsafat Yunani oleh umat Islam bersifat selektif dan kreatif. ${ }^{12}$ Yang diterjemahkan adalah filsafat dan ilmu-ilmu yang memberikan kemaslahan bagi umat seperti; kedokteran, pertanian, astronomi, ilmu bumi, ilmu ukur, dan ilmu bangunan.Sedangkan sastra Yunani ditinggalkan karena banyak berbau takhayul dan syirik.Dan ilmu-ilmu terjemahan tersebut tidak diterima begitu saja (taken for granted), melainkan dikembangkan dan diislamkan, mengingat pertumbuhan ilmuilmu Yunani Kuno bersifat sekuler.Oleh karena itu, perkembangan ilmu dalam Islam sangatberbeda dengan yang berkembang di Yunani.

Konsep ajaran Islam tentang pengembangan ilmu pengetahuan yang demikian itu, didasarkan pada beberapa prinsip sebagai berikut:

Pertama, ilmu pengetahuan dalam Islam dikembangkan dalam kerangka tauhid atau teologi, yaitu teologi yang bukan semata-mata meyakini adanya Tuhan dalam hati, mengucapkannya dengan lisan, dan mengamalkannya dengan tingkah laku, melainkan teologi yang menyangkut aktifitas mental berupa kesadaran manusia yang paling dalam perihal hubungan manusia dengan Tuhan, lingkungan, dan sesamanya. Dengan demikian dalam pandangan teologi, maka alam raya, manusia, masyarakat, dan Tuhan merupakan satu kesatuan yang saling berhubungan. Dengan prinsip tauhid ini, maka seluruh ilmu pengetahuan 
, baik ilmu yang mengkaji tentang alam (sains), maupun ilmu yang mengkaji manusia, masyarakat, dan wahyu, pada hakikatnya adalah ayatayat Allah. Bentuk dan macam ilmu itu berbeda-beda, tetapi hakikatnya satu. Dengan prinsip tauhid ini, maka seseorang akan sampai kepada Tuhan dengan menggunakan ilmu tersebut.

Kedua, ilmu pengetahuan dalam Islam hendaknya dikembangkan dalam rangka bertakwa dan beribadah kepada Allah SWT.Hal ini penting ditegaskan, karena dorongan al-Qur'an untuk mempelajari fenomena alam dan sosial tampak kurang diperhatikan, sebagai akibat dari perhatian dakwah Islam yang semula lebih tertuju untuk memperoleh keselamatan di akhirat.Hal ini mesti diimbangi dengan perintah mengabdi kepada Allah dalam arti luas, termasuk mengembangkan ilmu pengetahuan.motivasi pengembangan ilmu yang sejak dahulu dipraktikkan oleh para ilmuan muslim seperti al-farabi, Ibnu Rusyd, Ibnu Sina dan lainnya itu hendaknya dijadikan pegangan dalam pengembangan ilmu di masa sekarang. Dengan cara demikian, ilmu pengetahuan tidak akan digunakan untuk tujuan-tujuan yang membahayakan dan merugikan manusia serta lainnya yang bertentangan dengan kehendak Tuhan.

Ketiga, reorientasi pengembangan ilmu pengetahuan harus dimulai dengan suatu pemahaman yang segera dan kritis atas epistemologi Islam klasik dan rumusan kontemporer tentang konsep ilmu.Perubahan harus ditafsirkan dalam rangka struktur fisik luarnya, dan infrastruktur dari gagasan epistemologi Islam yang abadi harus dipulihkan dalam keseluruhannya.Dalam kaitan ini, maka pengembangan ilmu dalam bentuk lahiriyahnya, jangan sampai menghilangkan makna spritualnya yang abadi, yakni sebagai alat untuk menyaksikan kebesaran Tuhan. 
Keempat, ilmu pengetahuan harus dikembangkan oleh orang-orang Islam yang memiliki keseimbangan antara kecerdasan akal dengan kecerdasan moral yang dibarengi dengan kesungguhan untuk beribadah kepada Allah dalam arti yang seluas-luasnya. Hal ini sesuai dengan apa yang terjadi dalam sejarah di abad klasik, di mana para ilmuan yang mengembangkan ilmu pengetahuan adalah pribadi-pribadi yang senantiasa taat beribadah kepada Allah dan memiliki kesucian jiwa dan raga.

Kelima, ilmu pengetahuan harus dikembangkan dalam rangka yang integral, yakni bahwa antara ilmu agama dan ilmu umum walaupun bentuk formalnya berbeda-beda, namun hakikatnya sama, yaitu samasama sebagai tanda kekuasaan Allah. ${ }^{13}$

Dengan demikian, dalam sejarah perkembangannya ilmu pengetahuan Islam mengalami kemajuan dalam era klasik, namun setelah itu, perkembangan ilmu pengetahuan Islam mengalami kemunduran.

\section{KESIMPULAN}

Berdasarkan uraian dan analisis di atas, dapat penulis simpulkan sebagai berikut:

1. Ilmu pengetahuan adalah kumpulan pengetahuan yang dihasilkan melalui proses penelitian, pembuktian, pengujian, dan percobaan secara mendalam, sistematik, obyektif, dan komprehensif dengan menggunakan berbagai metode dan pendekatan dan berfungsi untuk memecahkan berbagai masalah yang dihadapi oleh manusia.

2. Epistemologi Islam adalah ilmu yang membahas tentang hakikat ilmu pengetahuan, sumber ilmu pengetahuan, metode ilmu pengetahuan, sertai nilai atau manfaat ilmu pengetahuan berdasarkan al-Qur'an dan Al-Sunnah. 
3. Sumber ilmu dalam Islam adalah alam jagat raya, fenomena sosial, akal, intuisi, dan wahyu. Sedangkan cara mengembangkan ilmu atau menyusunnya menjadi sebuah ilmu dapat dilakukan dengan menggunakan riset bayyani, ijbari, burhani, jadali, dan irfani.

4. Islam secara normatif, histroris,dan filosofis, sangat mendorong pengembangan ilmu pengetahuan, hal ini sebagaimana fakta yang terjadi di era zaman klasik bahwa ilmu pengetahuan Islam berkembang sangat pesat, namun dalam perkembangan saat ini pengembangan ilmu pengetahuan sudah mengalami kemunduran, hal ini antara lain dikarenakan redupnya etos keilmuan, tertutupnya pintu ijtihad, rendahnya penggunaan akal, serta orientasi kehidupannya lebih mengarah kepada kehidupan akhirat.

Penulis : Dr. Jaenullah, M.S.I adalah Dosen Tetap STIT Misbahul Ulum Gumawang OKU Timur Sumsel

\section{DAFTAR PUSTAKA}

Abdullah, M. Amin, Studi Agama Normativitas atau Historisitas, Yogyakarta : Pustaka Pelajar, 2002.

Al-Munjid fi al-Lughah wa al-A'lam, Beirut : Dār al-Masyriq, 1986.

Azizy, A.Qadri, Pengembangan Ilmu-Ilmu Keislaman, Jakarta: Direktorat Perguruan Tinggi Agama Islam Departemen Agama RI, 2003.

Azra, Azyumardi, Pendidikan Islam Tradisi dan Modernisasi Menuju Milenium Baru, Jakarta: Logos Wacana Ilmu, 1999.

D. Runes, Dagobert, Dictionary Of Philosophy, New Jersey, Little Field Adams \& CO, 1963.

Eksiklopedi Al-Qur'an, Jilid I, Jakarta: Yayasan Bimantara, 1997.

Fadjar, A. Malik, Reorientasi Pendidikan Islam, Jakarta: Fajar Dunia, 1999 
Hamlyn, D.W.,History Of Epistemology, dalam Paul Edwards, The Encyclopedia Of Philosophy, vol.3, 1967

Kertanegara, Mulyadi, Menembus Batas Panorama Filsafat Islam, Bandung: Mizan, 2002.

Munawwir, Ahmad Warson, Kamus Arab-Indonesia, Yogyakarta: Pondok Pesantren al-Munawwir, 1984.

Nasution, Harun, Islam Rasional; Gagasan dan Pemikirannya, Bandung: Mizan, 1996

Nata, Abuddin, dkk, Integrasi Ilmu Agama dan Ilmu Umum, Jakarta: PT RajaGrafindo Persada, 2005.

Nata, Abuddin, Manajemen Pendidikan; Mengatasi Kelemahan Pendidikan Islam di Indonesia, Jakarta: Kencana, 2010.

Rahardjo, M. Dawam, Ensiklopedi al-Qur'an: Ilmu, dalam Ulumul Qur'ān, Vol.1, No. 4, 1990.

Shihab, Quraish, Wawasan Al-Qur'an Tafsir Maudhu'I atas Pelbagai Persoalan Umat Islam, Bandung: Mizan, 1996.

Sholihin, M, Epistemologi Ilmu dalam Sudut Pandang Al-Ghazali,Bandung: Pustaka Setia, 2001.

Suhartono, Suparlan, Dasar-Dasar Filsafat, Yogyakarta: Ar-Ruzz, 2004.

Suriasumantri, Jujun S., Ilmu dalam Perspektif, Jakarta: Yayasan Obor Indonesia, 1999.

Syafrin, Nirwan, Kritik terhadap Kritik Akal Islam al-Jabiri, Islamia, Tahun I No.2/Juni-Agustus 2004.

Tim Penyusun Depdiknas, Kamus Bahasa Indonesia, Jakarta: Balai Pustaka, 2005.

Titus, Harold H., dkk.,Persoalan-Persoalan Filsafat, terj. M. Rasjidi, Jakarta: Bulan Bintang, 1984.

Yatim, Badri, Sejarah Peradaban Islam, Jakarta: Raja Grafindo Persada, 2005 
${ }^{1}$ Epistemologi diartikan sebagai filsafat tentang ilmu, yang didalam di bahas berbagai hal yang berkaitan dengan ilmu, antara lain hakikat ilmu, sumber ilmu (ontologi), macam-macam ilmu, alat untuk memperoleh ilmu, cara-cara yang dapat digunakan untuk memperoleh ilmu (metodologi), nilai-nilai yang terdapat dalam ilmu (aksiologi). Secara etimologi, epistemologi berasal dari bahasa Yunani "episteme", yang berarti ilmu, dan "logos" berarti cara memahami dan mempelajari. Dalam Bahasa Arab, epistemologi dapat dikenal dengan istilah ilmu fi al-ilmi atau nazhariyah al-ma'rifah. Lihat dalam buku Abuddin Nata, Sejarah Sosial Intelektual Islam dan Institusi Pendidikan Islam, (Jakarta: PT RajaGrafindo Persada, 2012), h. 209.Epistemologi adalahteori tentang ilmu yang membahas ilmu dan bagaimana memperolehnya, kemudian membahasnya secara mendalam (subtantif). Lihat dalam buku M. Sholihin, Epistemologi Ilmu Dalam Sudut Pandang Al-Ghazali,(Bandung: Pustaka Setia, 2001),h.9 danlihat juga dalam buku Harun Nasution, Filsafat Agama, (Jakarta: Bulan Bintang, 1973), h. 10

Sementara itu, secara terminologi, ada beberapa definisi yang diungkapkan oleh para ahli yang dapat dijadikan sebagai pijakan dalam memahami, apa sebenarnya epistemologi itu. D.W. Hamlyn mendefenisikan, epistemologi sebagai cabang filsafat yang berurusan dengan hakikat dan lingkup pengetahuan, dasar dan pengandaian-pengandaiannya, serta secara umum dapat diandalkannya sebagai penegasan bahwa orang memiliki pengetahuan. Lihat D.W. Hamlyn, History Of Epistemology, dalam Paul Edwards, The Encyclopedia Of Philosophy, vol.3, 1967, hh.8-9. Menurut Dagobert D. Runes, epistemologi adalah cabang filsafat yang membahas sumber, struktur, metode-metode, dan validitas pengetahuan. Lihat dalam buku Dagobert D. Runes, Dictionary Of Philosophy, (New Jersey, Little Field Adams \& CO, 1963), h. 49. Pendapat tidak jauh berbeda dikemukakan oleh Azyumardi Azra bahwa, epistemologi sebagai Ilmu yang membahas tentang keaslian, pengertian, struktur, metode, validitas ilmu pengetahuan.lihat Azyumardi Azra, Pendidikan Islam Tradisi dan Modernisasi Menuju Milenium Baru, (Jakarta: Logos Wacana Ilmu, 1999), h.114.

${ }^{2}$ Jujun S. Suriasumantri, Filsafat Ilmu: Sebuah Pengantar Populer,(Jakarta: Pustaka Sinar Harapan, 2005), h. 19

${ }^{3}$ Suparlan Suhartono, Dasar-Dasar Filsafat, (Yogyakarta: Ar-Ruzz, 2004), h. 73

${ }^{4}$ Harold H. Titus, dkk.,Persoalan-Persoalan Filsafat, terj. M. Rasjidi (Jakarta: BulanBintang, 1984), hlm. 198-203.

${ }^{5}$ Nirwan Syafrin, Kritik terhadap Kritik Akal Islam al-Jabiri, (Islamia, Tahun I No.2/JuniAgustus 2004), h. 43

${ }^{6}$ M. Amin Abdullah, Studi Agama Normativitas atau Historisitas?, (Yogyakarta : Pustaka Pelajar, 2002), h. 261

${ }^{7}$ Abuddin Nata, Manajemen Pendidikan; Mengatasi Kelemahan Pendidikan Islam di Indonesia, (Jakarta: Kencana, 2010), h. 111

${ }^{8}$ Ibid., h. 112

${ }^{9}$ Harun Nasution, Pembaharuan dalam Islam; Sejarah Pemikiran dan Gerakan, (Jakarta : Bulan Bintang, 1975), hh.13-14

${ }^{10}$ Harun Nasution, Falsafah dan Mistisisme dalam Islam, (Jakarta: Bulan Bintang, 1973), h. 11

${ }^{11}$ Lihat Badri Yatim, Sejarah Peradaban Islam, (Jakarta: PT RajaGrafindo Persada, 2005), h. 49-60 lihat juga dalam buku Harun Nasution, Islam Ditinjaui dari Berbagai Aspeknya, (Jakarta: UI Press, , 1979), hh. 70-73

${ }^{12}$ Harun Nasution, Islam Rasional; Gagasan dan Pemikirannya, (Bandung: Mizan, 1996), h. 299

${ }^{13}$ Abuddin Nata, Manajemen Pendidikan hh. 113-117 